\title{
Effectiveness of Diabetes Self-management Education Against Diet Behavior in Patients Type 2 Diabetes Mellitus: A Literature Review
}

\author{
Suardi Suardi ${ }^{1,2 *}$, Amran Razak $^{3}$, Ridwan Amiruddin ${ }^{4}$, Hasanuddin Ishak $^{5}$, Ummu Salmah $^{6}$, Ida leida Maria ${ }^{4}$ \\ ${ }^{1}$ Department of Public Health, Doctoral Student of Public Health, Hasanuddin University, Makassar, Indonesia; ${ }^{2}$ Department \\ of Nursing, High School of Health Science Tanawali Takalar, Makassar, Indonesia; ${ }^{3}$ Department of Health Policy and \\ Administration, Faculty of Public Health, Hasanuddin University, Makassar, Indonesia; ${ }^{4}$ Department of Epidemiology, Faculty \\ of Public Health, Hasanuddin University, Makassar, Indonesia; ${ }^{5}$ Department of Environmental Health, Faculty of Public Health, \\ Hasanuddin University, Makassar, Indonesia; ${ }^{6}$ Department of Biostatistics and Demographics, Faculty of Public Health, \\ Hasanuddin University, Makassar, Indonesia
}

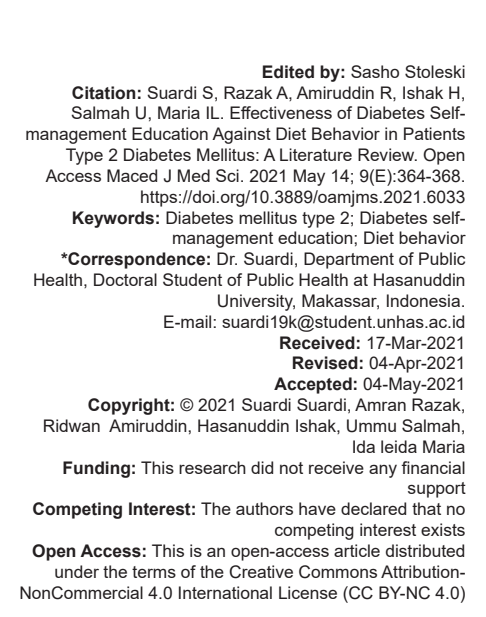

Abstract

BACKGROUND: Diabetes mellitus (DM) is a disease that describes a problem with insulin deficiency and the inability of the pancreas to produce enough insulin. The World Health Organization predicts that the number of people with DM type II in Indonesia will increase to 12 million by 2030.

AIM: This study looks at Journals on diabetes selfmanagement education (DSME) on DM patients in improving dietary behavior.

METHODS: This study uses an online journal database that provides free articles and journals in PDF such as: ProQuest, EBCSO, PubMed, Elsevier, Scinapse, MDPI, and Google Scholar. Literature was collected from the past 10 years, namely, 2010-2020 using the following set of keywords: "DSME," "DSME Program Evaluation," and "Diabetes Self-Care Education."

RESULTS: DSME intervention can improve the condition of DM patients if it is routinely carried out. In addition, the DSME intervention was able to control hemoglobin A1c levels and control blood sugar. This intervention still needs to be developed, considering that various forms of education in DM patients have been carried out such as using text messages, leaflets, illustrated pictures or leaflets, by telephone, video, handbooks, or direct education. These investigations can be developed into empirical research.

CONCLUSIONS: The application of DSME interventions can help improve the conditions experienced by DM type II sufferers if it is routinely carried out.

\section{Introduction}

Diabetes mellitus (DM) is a chronic metabolic disease, which is emerging as a major public health problem. The worldwide prevalence of diabetes in adults is estimated at $4.0 \%$ in 1995 and is expected to increase to $5.4 \%$ in 2025 . The number of adults with diabetes in Indonesia is expected to increase from 6.9 million in 2010 to 12 million in 2030 [1]. DM is an established risk factor for several causes of death, including ischemic heart disease, stroke, kidney disease, infectious diseases, and some cancers [2].

DM is a health problem that is increasing worldwide. It is estimated that there will be 552 million patients with diabetes and 300 million people with impaired glucose tolerance by 2030 [3]. According to the International Diabetes Federation (IDF), >382 million people worldwide had diabetes in 2012; that number is expected to grow to 592 million by 2035 [4]. In 2015, there were 415 million people with diabetes worldwide (91\% of whom were type 2 diabetes) with a figure expected to increase to 642 million by 2040 [5].

The prevalence of DM will continue to increase every year, and data from the IDF show that the number of patients diagnosed with DM in Indonesia is estimated to increase from 10.3 million in 2017 to 16.7 million in 2045 [6].

One study in India reported that $63 \%$ of patients who were not adherent to the diet program and glucose monitoring were involved. A 2010 Delamater study showed approximately $48 \%$ of patients did not follow a diet plan and physical activity program. He also reported that $70 \%$ of patients were not adherent to the high carbohydrate and high-fiber diet program [7].

The purpose of this study was to determine the effectiveness of diabetes self-management education (DSME) on dietary behavior in type 2 DM patients. The systematic review process is shown in Figure 1. 


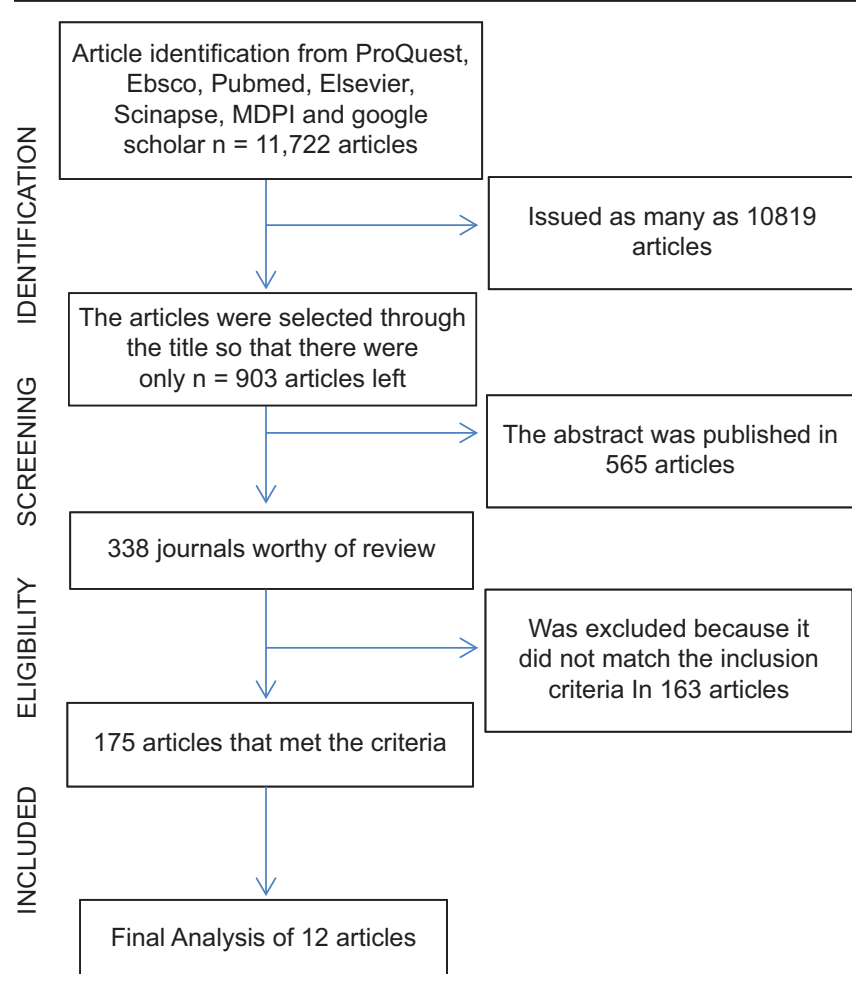

Figure 1: Input and output diagram of primary studies to final synthesis

\section{Methods}

This study looks at online journal databases that provide free national and international articles and journals in PDF form such as Google Scholar, Academia.edu, ProQuest, EBSCO, PUBMED, Elsevier, and Scinapse. Other sources such as textbooks from libraries, national health reports, theses, and dissertations are also used as well as research results abstracts or proceedings, to keep information up-todate. The information used is mainly from literature collected from the past 10 years from 2010 to 2020 , based on the following set of keywords: "DSME "DSME Program Evaluation," and "Diabetes Self-Care Education."

The writing of this literature review refers to the Preferred Reporting Items for Systematic Reviews guidelines. The review stage is the identification of articles from the source data base (identification), filtering articles based on inclusion and exclusion

Table 1: List of articles on criteria in the literature review

\begin{tabular}{ll}
\hline Inclusion & Exclusion \\
\hline The literature taken is literature & Just abstract \\
that discusses DSME in DM & \\
patients & \\
DSME intervention gives results & Incomplete text \\
or impacts on DM sufferers & \\
The population studied is clear & Double publication \\
Full texts & The population studied is unclear \\
Journals published in the past & \\
10 years (2010-2020) & \\
English language articles & \\
Open access & \\
\hline DSME: Diabetes self-management education, DM: Diabetes mellitus.
\end{tabular}

in Table 1 (screening) criteria, selecting all articles that match the inclusion criteria (eligibility), and determining articles that match the design of the DSME research plan) included. The total articles obtained from Scinapse, PUBMED, and Google Scholar are 11,722 articles.

\section{Results}

The systematic review of DSME in improving dietary behavior is summarized in Table 2 .

\section{Discussion}

DSME is an important component in providing quality care to all diabetics. DSME helps patients develop the knowledge, skills, and abilities necessary for effective self-care. Diabetes programs as a behavioral and psychosocial strategy to facilitate self-care so as to provide better results. Several DSME interventions are capable of providing effective change in promoting behavior change [19]. DSME as an effective education, cost protection, can prevent complications. A variety of culturally appropriate services is offered as a form of regulation, utilizes technology, facilitates access to DSME services, makes self-management decisions, and reduces the likelihood of complications [10], [20]. DSME has positive effects on the clinical, psychosocial, and behavioral aspects of diabetes [20].

Diabetes self-management is a form of diabetes health education to improve health knowledge and behavior [21]. Diet modification, physical activity, stress management, and pharmacological therapy all play a role in achieving the desired outcome for diabetes [4]. Diabetes selfmanagement support refers to the support needed to apply and maintain skills and behaviors in a sustainable manner [22]. The Society of Behavioral Medicine explains that DSME and support is the basis for DM sufferers regarding diabetes management to reduce complications [23]. Thus, implementation of support education considers effective in preventing the development of diabetic foot ulcer (DFU), including signs of pre ulcer.

Of all, strategies that can be used to prevent ulcers and further complications in DM patients include educational support to patients, multidisciplinary treatment, close monitoring, and prevention of DFU, including signs of pre ulcer. 
Table 2: Information on DSME on diet behavior

\begin{tabular}{|c|c|c|c|c|c|c|c|}
\hline No. & Author/Year/Title & Subject & Study objective & Design & Study outcome & Recommendation & $\begin{array}{l}\text { Variable } \\
\text { researched }\end{array}$ \\
\hline 1. & $\begin{array}{l}\text { [8] Assessment } \\
\text { of a National } \\
\text { Diabetes Education } \\
\text { Program diabetes } \\
\text { management } \\
\text { booklet: The } \\
\text { Glycemic Reduction } \\
\text { Approach to } \\
\text { Diabetes: A } \\
\text { Comparative } \\
\text { Effectiveness Study } \\
\text { (GRADE) experience }\end{array}$ & $\begin{array}{l}348 \text { adults with } \\
\text { type } 2 \text { diabetes } \\
\text { data were taken } \\
\text { from October } \\
2013 \text { to June } \\
2014\end{array}$ & $\begin{array}{l}\text { To explore the impact } \\
\text { of the } 4 \text { steps on } \\
\text { participants' knowledge } \\
\text { of diabetes management } \\
\text { and self-reliance in a } \\
\text { GRADE }\end{array}$ & Pre- and post-test & $\begin{array}{l}\text { The findings of this study } \\
\text { suggest that the } 4 \text { steps booklet } \\
\text { can help primary health-care } \\
\text { providers to educate and support } \\
\text { patients with type } 2 \text { diabetes and } \\
\text { improve knowledge of diabetes } \\
\text { management and self-efficacy }\end{array}$ & $\begin{array}{l}\text { Diabetes education requires } \\
\text { a variety of interventions and } \\
\text { tools, and diabetes education } \\
\text { programs must continue } \\
\text { to produce accessible and } \\
\text { evidence-based information } \\
\text { for patients, providers, and } \\
\text { partners to help prevent and } \\
\text { manage diabetes }\end{array}$ & $\begin{array}{l}\text { Knowledge and } \\
\text { self-efficacy }\end{array}$ \\
\hline 2. & $\begin{array}{l}\text { [9] Effectiveness } \\
\text { of a diabetes } \\
\text { education and } \\
\text { self-management } \\
\text { program } \\
\text { (DESMOND) } \\
\text { for people with } \\
\text { newly diagnosed } \\
\text { type } 2 \text { DM: } 3 \text {-year } \\
\text { follow-up of a } \\
\text { cluster randomized } \\
\text { controlled trial (RCT) } \\
\text { in primary care }\end{array}$ & $\begin{array}{l}\text { DM patients } \\
\text { in } 207 \text { general } \\
\text { practices in } 13 \\
\text { primary care } \\
\text { centers in the } \\
\text { UK. Follow-up } \\
3 \text { years }\end{array}$ & $\begin{array}{l}\text { To assess the } \\
\text { effectiveness of } \\
\text { DESMOND for people } \\
\text { with newly diagnosed } \\
\text { type } 2 \text { DM }\end{array}$ & Cluster RCT & $\begin{array}{l}\text { Hemoglobin A1c ( } \mathrm{HbA} 1 \mathrm{c} \text { ) levels at } \\
3 \text { years decreased in both groups. } \\
\text { However, the difference was not } \\
\text { significant (difference }-0.02,95 \% \\
\text { confidence interval }-0.22-0.17 \text { ) } \\
\text { after the intervention. The same } \\
\text { is the case for biomedical and } \\
\text { another lifestyle and drug use. the } \\
\text { depression scores and quality of } \\
\text { life did not differ at } 3 \text { years }\end{array}$ & $\begin{array}{l}\text { Future studies will need to } \\
\text { include a longer follow-up } \\
\text { period to produce an } \\
\text { understanding of the effects of } \\
\text { the intervention overtime }\end{array}$ & $\begin{array}{l}\text { Biomedical, } \\
\text { lifestyle, } \\
\text { depression score, } \\
\text { and quality of life }\end{array}$ \\
\hline 3. & $\begin{array}{l}\text { [3] The Effect of } \\
\text { DSME on Body } \\
\text { Weight, Glycemic } \\
\text { Control, and Other } \\
\text { Metabolic Markers in } \\
\text { Patients with Type } 2 \\
\text { DM }\end{array}$ & $\begin{array}{l}76 \text { patients with } \\
\text { type } 2 \text { diabetes }\end{array}$ & $\begin{array}{l}\text { To evaluate the effect } \\
\text { of short-term DSME } \\
\text { on metabolic markers } \\
\text { and atherosclerotic } \\
\text { parameters in patients } \\
\text { with type } 2 \text { diabetes }\end{array}$ & $\begin{array}{l}\text { Two-group } \\
\text { experimental design }\end{array}$ & $\begin{array}{l}\text { DSME can increase } \mathrm{HbA} 1 \mathrm{c} \text { and } \\
\text { body weight in patients with type } \\
2 \text { diabetes }\end{array}$ & $\begin{array}{l}\text { - The time intervals from } \\
\text { baseline and assessment } \\
\text { of follow-up were relatively } \\
\text { short. Therefore, the } \\
\text { possible changes in } \\
\text { CIMT, CAS, and some } \\
\text { of the metabolic markers } \\
\text { associated with DSME were } \\
\text { not demonstrated } \\
\text { - The long-term effect of } \\
\text { intensity self-management } \\
\text { education in diabetic } \\
\text { patients was not fully } \\
\text { evaluated in this study } \\
\text { - The study size was small } \\
\text { with only } 36 \text { patients in the } \\
\text { intervention group and } 40 \\
\text { patients in the control group. } \\
\text { Further investigation of the } \\
\text { long-term effects of DSME } \\
\text { and with a larger sample } \\
\text { size is suggested }\end{array}$ & $\begin{array}{l}\text { Weight, glycemic } \\
\text { control, and } \\
\text { marker }\end{array}$ \\
\hline 4. & $\begin{array}{l}\text { [10] The Efficacy } \\
\text { of Diabetes Patient } \\
\text { Education and } \\
\text { Self-Management } \\
\text { Education in Type } 2 \\
\text { Diabetes }\end{array}$ & $\begin{array}{l}\text { Adults with } \\
\text { diabetes type } 2\end{array}$ & $\begin{array}{l}\text { To compare 6-month } \\
\text { progress in diabetes } \\
\text { patient education } \\
\text { with a supplementary } \\
\text { education model with } \\
\text { a self-management } \\
\text { program }\end{array}$ & $\begin{array}{l}\text { The experimental } \\
\text { group subjects } \\
\text { and control group } \\
\text { subjects }\end{array}$ & $\begin{array}{l}\text { There were statistically significant } \\
\text { improvements in both groups } \\
\text { in terms of glycated HbA1c and } \\
\text { body weight, and the experimental } \\
\text { group had statistically significant } \\
\text { improvements in four additional } \\
\text { results }\end{array}$ & $\begin{array}{l}\text { It needs to be extrapolated } \\
\text { to a larger adult population } \\
\text { with type } 2 \text { diabetes who } \\
\text { is referred to a diabetes } \\
\text { education center }\end{array}$ & $\begin{array}{l}\mathrm{HbA} 1 \mathrm{c} \text { and weight } \\
\text { loss }\end{array}$ \\
\hline 5. & $\begin{array}{l}\text { [11] Persian DSME } \\
\text { (PDSME) program: } \\
\text { evaluation of } \\
\text { effectiveness in Iran }\end{array}$ & $\begin{array}{l}\text { Individuals aged } \\
18 \text { years and } \\
\text { over }\end{array}$ & $\begin{array}{l}\text { To design the PDSME } \\
\text { program using } \\
\text { intervention mapping to } \\
\text { assess the effectiveness } \\
\text { of the program in people } \\
\text { newly diagnosed with } \\
\text { type } 2 \text { diabetes and } \\
\text { those who received } \\
\text { little self-management } \\
\text { education }\end{array}$ & $\begin{array}{l}\text { Two-group } \\
\text { experimental design }\end{array}$ & $\begin{array}{l}\text { The PDSME group showed a } \\
\text { significant increase in mean HbA1c } \\
(-1.1 \text { versus }+0.2 \%, P=0.008 \text {. } \\
\text { Knowledge of diabetes increased } \\
\text { more in PDSME patients treated } \\
\text { with oral antidiabetic agents than in } \\
\text { those receiving usual care overtime } \\
(\mathrm{RMA}),(\mathrm{F}=67.08, P<0.001) . \mathrm{A} \\
\text { statistically significant improvement } \\
\text { was seen in PDSME patients for } \\
\text { self-care behavior, health beliefs, } \\
\text { attitudes toward diabetes, stigma, } \\
\text { self-efficacy, and patient satisfaction }\end{array}$ & $\begin{array}{l}\text { Researchers must find } \\
\text { ways to identify and help } \\
\text { hard-to-reach patients }\end{array}$ & $\begin{array}{l}\text { HbA1C, } \\
\text { knowledge, } \\
\text { self-care activities, } \\
\text { psychosocial, and } \\
\text { depression }\end{array}$ \\
\hline 6. & $\begin{array}{l}\text { [12] Effectiveness } \\
\text { of DSME through } \\
\text { a smartphone } \\
\text { application in insulin } \\
\text { treated type } 2 \\
\text { diabetes patients } \\
\text { - design of a RCT } \\
\text { ("TRIGGER study") }\end{array}$ & $\begin{array}{l}\text { Patients } \\
\text { DM aged } \\
40-70 \text { years, } \\
\text { undergoing } \\
\text { insulin therapy } \\
\text { for at least } 3 \\
\text { months, Control } \\
\text { group } 114 \text { and } \\
\text { intervention } \\
\text { group } 114 \\
\text { respondents, } \\
\text { follow-up } 3 \\
\text { months }\end{array}$ & $\begin{array}{l}\text { To evaluate the } \\
\text { effectiveness of DSME } \\
\text { through a smartphone } \\
\text { application in T2DM } \\
\text { patients on insulin therapy }\end{array}$ & $\begin{array}{l}\text { Non-blinded } \\
\text { two-arm multicenter } \\
\text { randomized } \\
\text { controlled superiority } \\
\text { trial with parallel } \\
\text { groups and equal } \\
\text { randomization } \\
\text { (“TRIGGER study”) }\end{array}$ & $\begin{array}{l}\text { Innovative solutions are needed } \\
\text { to increase the effectiveness of } \\
\text { self-management, for an increasing } \\
\text { number of T2DM patients. This } \\
\text { trial will provide evidence of the } \\
\text { effectiveness of a newly developed } \\
\text { smartphone application designed to } \\
\text { promote diabetes self-management }\end{array}$ & $\begin{array}{l}\text { There should be policies } \\
\text { aimed at improving diabetes } \\
\text { self-management }\end{array}$ & $\begin{array}{l}\text { HbA1C, behavior } \\
\text { change, } \\
\text { cost-effectiveness }\end{array}$ \\
\hline
\end{tabular}


Table 2: (Continued)

\begin{tabular}{|c|c|c|c|c|c|c|c|}
\hline No. & Author/Year/Title & Subject & Study objective & Design & Study outcome & Recommendation & $\begin{array}{l}\text { Variable } \\
\text { researched }\end{array}$ \\
\hline 7. & $\begin{array}{l}13] \text { The effect } \\
\text { of text message } \\
\text { support on diabetes } \\
\text { self-management in } \\
\text { developing countries } \\
\text {-A randomized trial }\end{array}$ & $\begin{array}{l}480 \text { adults with } \\
\text { diabetes (Type } 1 \\
\text { or type 2) }\end{array}$ & $\begin{array}{l}\text { To assess differences in } \\
\text { the proportion of subjects } \\
\text { in diabetic patients with } \\
\text { the DSME program group } \\
\text { and DSME+diabetes } \\
\text { self-management support } \\
\text { (DSMS) }\end{array}$ & RCT & $\begin{array}{l}\text { The proportion of subjects with } \\
\text { controlled HbA1c was } 2.8 \% \text { higher } \\
\text { in the intervention group than in the } \\
\text { control group (the difference was } \\
\text { not statistically significant). }\end{array}$ & $\begin{array}{l}\text { MHealth can be a useful tool } \\
\text { for health-care providers, } \\
\text { in reaching out to patients; } \\
\text { it may be more interesting } \\
\text { to examine more dynamic } \\
\text { mechanisms to improve } \\
\text { mutual connectivity between } \\
\text { patients, providers, and } \\
\text { support systems. }\end{array}$ & HbA1C \\
\hline 8. & $\begin{array}{l}\text { [14] DSME - Effect } \\
\text { on Knowledge, } \\
\text { Self-care Behavior, } \\
\text { and Self-efficacy } \\
\text { Among Type } 2 \\
\text { Diabetes Patients } \\
\text { in Ethiopia: A } \\
\text { Controlled Clinical } \\
\text { Trial }\end{array}$ & $\begin{array}{l}\text { Patients with } \\
\text { type } 2 \text { DM, } 116 \\
\text { intervention } \\
\text { groups and } 104 \\
\text { comparison } \\
\text { groups }\end{array}$ & $\begin{array}{l}\text { To determine the effect } \\
\text { of DSME on diabetes } \\
\text { knowledge, self-care } \\
\text { behavior, and self-efficacy } \\
\text { were measured at } \\
\text { baseline and at } 9 \text { months } \\
\text { after initiation of the } \\
\text { DSME intervention (end } \\
\text { point) in both groups }\end{array}$ & $\begin{array}{l}\text { Two-group } \\
\text { experimental design }\end{array}$ & $\begin{array}{l}\text { The study found significant } \\
\text { improvements in the intervention } \\
\text { participants' diabetes knowledge } \\
\text { scores and their adherence to diet } \\
\text { and foot care recommendations. } \\
\text { This suggests that our DSME } \\
\text { intervention may be of clinical } \\
\text { importance in a developing country } \\
\text { like Ethiopia }\end{array}$ & $\begin{array}{l}\text { This DSME is important } \\
\text { and enhances the } \\
\text { self-management capacity } \\
\text { of T2DM patients in } \\
\text { low-resource settings but } \\
\text { requires further assurance in } \\
\text { development and testing for } \\
\text { use in developing countries }\end{array}$ & $\begin{array}{l}\text { Knowledge, } \\
\text { self-care behavior, } \\
\text { and self-efficacy }\end{array}$ \\
\hline 9. & $\begin{array}{l}\text { [15] Comparative } \\
\text { Effectiveness of } \\
\text { a Mindful Eating } \\
\text { Intervention } \\
\text { to a Diabetes } \\
\text { Self-Management } \\
\text { Intervention among } \\
\text { Adults with Type } 2 \\
\text { Diabetes: A Pilot } \\
\text { Study }\end{array}$ & $\begin{array}{l}\text { Patients with } \\
\text { type } 2 \text { diabetes } \\
\text { for } 1 \text { year or } \\
\text { more aged } \\
35-65 \text { years }\end{array}$ & $\begin{array}{l}\text { To determine the } \\
\text { effectiveness of a mindful } \\
\text { eating intervention for } \\
\text { diabetes independent } \\
\text { management }\end{array}$ & RCT & $\begin{array}{l}\text { There were no significant } \\
\text { differences between groups in } \\
\text { changes in body weight or glycemia } \\
\text { at the end of the study. Significant } \\
\text { differences occurred between } \\
\text { groups in changes in food intake }\end{array}$ & $\begin{array}{l}\text { Further studies focused } \\
\text { on treatment (i.e., MNT vs. } \\
\text { dietary attention vs. treatment } \\
\text { combination) and whether } \\
\text { the magnitude of change was } \\
\text { greater when patients chose } \\
\text { one of the above approaches. } \\
\text { Alternatively, some patients } \\
\text { may have diabetes prefer } \\
\text { to complete a DSME based } \\
\text { course first to study MNT } \\
\text { basics and self-management } \\
\text { are followed }\end{array}$ & $\begin{array}{l}\text { Diet, physical } \\
\text { activity, body } \\
\text { weight, HbA1c } \\
\text { and fasting } \\
\text { plasma glucose, } \\
\text { and fasting insulin }\end{array}$ \\
\hline 10. & $\begin{array}{l}\text { [16] Evaluating } \\
\text { the Impact of } \\
\text { DSME Methods on } \\
\text { Knowledge, Attitude, } \\
\text { and Behavior (KAB) } \\
\text { of Patients with Type } \\
2 \text { DM }\end{array}$ & $\begin{array}{l}\text { Patients with } \\
\text { type } 2 \text { diabetes } \\
\text { were } 21 \text { people }\end{array}$ & $\begin{array}{l}\text { Comparing the } \\
\text { effectiveness of the } \\
\text { two methods DSME } \\
\text { by examining changes } \\
\text { HbA1c, KAB after } \\
\text { traditional group education } \\
\text { (TE) or with diabetes map } \\
\text { conversation (CM). The } \\
\text { CM group was postulated } \\
\text { to show a greater } \\
\text { decrease in A1C and an } \\
\text { improved score KAB was } \\
\text { compared with the TE } \\
\text { group }\end{array}$ & RCT & $\begin{array}{l}\text { The results of the study were } \\
\text { reported to have a significant } \\
\text { impact on increasing HbA1C levels, } \\
\text { diabetes knowledge, attitudes } \\
\text { toward diabetes, and self-care } \\
\text { behavior from baseline to } 3 \text { months } \\
\text { thereafter }\end{array}$ & $\begin{array}{l}\text { How to make diabetes } \\
\text { education programs more } \\
\text { effective in meeting patients' } \\
\text { needs and changing } \\
\text { their attitudes/behaviors } \\
\text { for long-term diabetes } \\
\text { self-management taking } \\
\text { into account demographic/ } \\
\text { psychosocial characteristics } \\
\text { and diabetes educator skills/ } \\
\text { experiences in teaching }\end{array}$ & $\mathrm{KAB}, \mathrm{HbA} 1 \mathrm{C}$ \\
\hline 11. & $\begin{array}{l}\text { [17] The Effects of } \\
\text { Intensive Nutrition } \\
\text { Education on Late } \\
\text { Middle-Aged Adults } \\
\text { with Type } 2 \text { Diabetes }\end{array}$ & $\begin{array}{l}196 \text { patients } \\
\text { between the } \\
\text { ages of } 50 \text { and } \\
65 \text { met the } \\
\text { criteria for type } 2 \\
\text { diabetes }\end{array}$ & $\begin{array}{l}\text { To investigate whether } \\
\text { intensive nutrition } \\
\text { education would benefit } \\
\text { middle-aged patients with } \\
\text { type } 2 \text { diabetes }\end{array}$ & RCT & $\begin{array}{l}\text { Intensive nutritional education } \\
\text { has a significant effect on blood } \\
\text { glucose control in middle-aged } \\
\text { adults with type } 2 \text { diabetes. } \\
\text { Intensive education can foster } \\
\text { good dietary habits and increase } \\
\text { physical activity, which is important } \\
\text { for diabetic patients in the short } \\
\text { and long term }\end{array}$ & $\begin{array}{l}\text { Generalization of programs } \\
\text { for patients with type } 2 \\
\text { diabetes from various cultural } \\
\text { backgrounds }\end{array}$ & $\begin{array}{l}\text { Knowledge, diet, } \\
\text { exercise, and } \\
\text { blood glucose } \\
\text { control }\end{array}$ \\
\hline 12. & $\begin{array}{l}\text { [18] Effectiveness } \\
\text { of A Multifactorial } \\
\text { Intervention in } \\
\text { Increasing Adherence } \\
\text { to the Mediterranean } \\
\text { Diet (MD) among } \\
\text { Patients with DM } \\
\text { Type 2: A Controlled } \\
\text { and Randomized } \\
\text { Study (EMID Study) }\end{array}$ & $\begin{array}{l}204 \text { subjects } \\
\text { between } 25 \text { and } \\
70 \text { years with } \\
\text { T2DM }\end{array}$ & $\begin{array}{l}\text { To assess the } \\
\text { effectiveness of } \\
\text { multifactorial interventions } \\
\text { to improve adherence to } \\
\text { MD, dietary quality, and } \\
\text { biomedical parameters }\end{array}$ & $\begin{array}{l}\text { Randomized and } \\
\text { controlled }\end{array}$ & $\begin{array}{l}\text { This multifactorial intervention } \\
\text { improved adherence to MD and } \\
\text { quality of diet among patients with } \\
\text { T2DM }\end{array}$ & $\begin{array}{l}\text { The exposure to the } \\
\text { intervention was short } \\
\text { ( } 3 \text { months) so that it could be } \\
\text { considered in future studies, } \\
\text { in addition, it is multifactorial } \\
\text { the intervention made it } \\
\text { impossible to know which } \\
\text { components resulted in } \\
\text { changes in group learning }\end{array}$ & $\begin{array}{l}\text { Compliance, } \\
\text { quality, and } \\
\text { biomedical }\end{array}$ \\
\hline
\end{tabular}

\section{Conclusions}

DSME has been shown to improve knowledge, behavior, and self-management. To overcome many disorders associated with the care of type 2 DM patients, various forms of education for DM patients have been carried out such as using text messages, leaflets, illustrated pictures, or leaflets, through telephone, video, handbooks, or direct education. DSME intervention, in the previous studies, focused more on knowledge, attitudes, foot care behavior, body weight, $\mathrm{HbA} 1 \mathrm{C}$, and glycemic control.

\section{References}

1. Soewondo P, Soegondo S, Suastika K, Pranoto A, dan Soeatmadji DW. The DiabCare Asia 2008 study outcomes on control and complications of Type 2 diabetic patients in 
Indonesia. Med J Indones. 2010;19(4):235-44. https://doi. org $/ 10.13181 / \mathrm{mji} . v 19 i 4.412$

2. Brownrigg JR, Griffin M, Hughes CO, Jones KG, Patel N, Thompson MM, et al. Influence of foot ulceration on causespecific mortality in patients with diabetes mellitus. J Vasc Surg. 2014;60(4):982-6.e3. https://doi.org/10.1016/j.jvs.2014.04.052 PMid:24865783

3. Yuan C, Lai CW, Chan LW, Chow M, Law HK, dan Ying M. The effect of diabetes self-management education on body weight, glycemic control, and other metabolic markers in patients with Type 2 diabetes mellitus. J Diabetes Res 2014;2014:789761. https://doi.org/10.1155/2014/789761

PMid:25136645

4. Ghafoor E, Riaz M, Eichorst B, Fawwad A, dan Basit A Evaluation of diabetes conversation map $^{\mathrm{TM}}$ education tools for diabetes self-management education. Diabetes Spectr. 2015;28(4):230-235. https://doi.org/10.2337/diaspect.28.4.230 PMid:26600723

5. Cradock KA, ÓLaighin G, Finucane FM, Gainforth HL, Quinlan LR, dan Ginis KA. Behaviour change techniques targeting both diet and physical activity in Type 2 diabetes: A systematic review and meta-analysis. Int J Behav Nutr Phys Act 2017;14(1):18. https://doi.org/10.1186/s12966-016-0436-0 PMid:28178985

6. Abrar EA, Yusuf S, Sjattar EL, dan Rachmawaty R. Development and evaluation educational videos of diabetic foot care in traditional languages to enhance knowledge of patients diagnosed with diabetes and risk for diabetic foot ulcers. Prim Care Diabetes. 2020;14(2):104-10. https://doi.org/10.1016/j.pcd.2019.06.005

PMid:31311727

7. Triyanto E, Isworo A, dan Rahayu E. Model pemberdayaan terpadu untuk meningkatkan kepatuhan pasien diabetes mellitus. J MKMI. 2015;11(4):228-34.

8. Devchand R, Nicols C, Gallivan JM, Tiktin M, KrauseSteinrauf $\mathrm{H}$, Larkin $\mathrm{M}$, et al. Assessment of a national diabetes education program diabetes management booklet: The GRADE experience. J Am Assoc Nurse Pract. 2017;29(5):255-63. https://doi.org/10.1002/2327-6924.12445

PMid:28213915

9. Khunti K, Gray LJ, Skinner T, Carey ME, Realf K, Dallosso H, et al. Effectiveness of a diabetes education and self management programme (DESMOND) for people with newly diagnosed Type 2 diabetes mellitus: Three year follow-up of a cluster randomised controlled trial in primary care. BMJ. 2012;344(7860):e2333. https://doi.org/10.1136/bmj.e2333

PMid:22539172

10. McGowan P. The efficacy of diabetes patient education and self-management education in Type 2 diabetes. Can J Diabetes. 2011;35(1):46-53. https://doi.org/10.1016/ s1499-2671(11)51008-1

11. Shakibazadeh E, Bartholomew LK, Rashidian A, dan Larijani B. Persian diabetes self-management education (PDSME) program: Evaluation of effectiveness in Iran. Health Promot Int. 2016;31(3):623-34. https://doi.org/10.1093/heapro/dav006 PMid:25761821

12. Boels AM, Rutten $G$, Zuithoff $N$, De Wit A, dan Vos R. Effectiveness of diabetes self-management education via a smartphone application in insulin treated Type 2 diabetes patients design of a randomised controlled trial ("TRIGGER study"). BMC Endocr Disord. 2018;18(1):74. https://doi. org/10.1186/s12902-018-0304-9

PMid:30348142

13. Van Olmen J, Kegels G, Korachais C, de Man J, Van Acker K, Kalobu JC, et al. The effect of text message support on diabetes self-management in developing countries a randomised trial. $\mathrm{J}$
Clin Transl Endocrinol. 2017;7:33-41. https://doi.org/10.1016/j. jcte.2016.12.005

PMid:29067248

14. Hailu FB, Moen A, dan Hjortdahl P. Diabetes self-management education (DSME) effect on knowledge, self-care behavior, and self-efficacy among Type 2 diabetes patients in Ethiopia: A controlled clinical trial. Diabetes Metab Syndr Obes Targets Ther. 2019;12:2489-99. https://doi.org/10.2147/dmso.s223123 PMid:31819574

15. Miller CK, Kristeller JL, Headings A, Nagaraja H, dan Miser WF. Comparative effectiveness of a mindful eating intervention to a diabetes self-management intervention among adults with Type 2 diabetes: A pilot study. J Acad Nutr Diet. 2012;112(11):183542. https://doi.org/10.1016/j.jand.2012.07.036 PMid:23102183

16. Adam L, O'Connor C, dan Garcia AC. Evaluating the impact of diabetes self-management education methods on knowledge, attitudes and behaviours of adult patients with Type 2 diabetes mellitus. Can J Diabetes. 2018;42(5):470-7.e2. https://doi. org/10.1016/j.jcjd.2017.11.003

17. Li $Y, X u M$, Fan $R$, Ma $X, G u J$, Cai $X$, et al. The effects of intensive nutrition education on late middle-aged adults with Type 2 diabetes. Int J Environ Res Public Health. 2016;13(9):897. https://doi.org/10.3390/ijerph13090897 PMid:27618080

18. Alonso-Domínguez R, García-Ortiz L, Patino-Alonso MC, Sánchez-Aguadero N, Gómez-Marcos MA, dan Recio-Rodríguez $\mathrm{JI}$. Effectiveness of a multifactorial intervention in increasing adherence to the mediterranean diet among patients with diabetes mellitus Type 2: A controlled and randomized study (EMID study). Nutrients. 2019;11(1):162. https://doi.org/10.3390/nu11010162 PMid:30646500

19. Miller CK, Kristeller JL, Headings $A$, dan Nagaraja $H$. Comparison of a mindful eating intervention to a diabetes self-management intervention among adults with Type 2 diabetes: A randomized controlled trial. Health Educ Behav. 2014;41(2):145-54. https://doi.org/10.1177/1090198113493092 PMid:23855018

20. Powers MA, Bardsley JK, Cypress M, Funnell MM, Harms D, Hess-Fischl A, et al. Diabetes self-management education and support in adults with Type 2 diabetes: A consensus report of the American Diabetes Association, the association of diabetes care and education specialists, the academy of nutrition and dietetics, the American Academy of Family Physicians, the American Academy of PAs, the American Association of Nurse Practitioners, and the American Pharmacists Association. Diabetes Care. 2020;43(7):1636-49. https://doi.org/10.2337/dci20-0023 PMid:32513817

21. Liu Y, Han Y, Shi J, Li R, Li S, Jin N, et al. Effect of peer education on self-management and psychological status in Type 2 diabetes patients with emotional disorders. J Diabetes Investig. 2015;6(4):479-86. https://doi.org/10.1111/jdi.12311 PMid:26221528

22. Powers MA, Bardsley J, Cypress M, Duker P, Funnell MM, Fischl AH, et al. Diabetes self-management education and support in Type 2 diabetes: A joint position statement of the American Diabetes Association, the American Association of Diabetes Educators, and the Academy of Nutrition and Dietetics. Diabetes Care. 2015;38(7):1372-82. https://doi.org/10.2337/dc15-0730 PMid:26048904

23. Sharp LK, Fisher EB, dan Gerber BS. Background and rationale for the society of behavioral medicine's position statement: Expand United States health plan coverage for diabetes selfmanagement education and support. Transl Behav Med. 2015;5(3):354-6. https://doi.org/10.1007/s13142-015-0328-x PMid:26327941 